\title{
THE FACTORS DRIVING INTEREST RATE SPREAD OF COMMERCIAL BANKS: EMPIRICAL EVIDENCE FROM NEPAL
}

\author{
Dr. BISHNU PRASAD BHATTARAI \\ Academic Director / Business Unit Head, Excel Business College, Pokhara University Affiliated,
} New Baneshwor, Kathmandu \& Faculty Member, Faculty of Management, Patan Multiple Campus,

Tribhuvan University, Patan Dhoka, Lalitpur, Nepal

The study has investigated the determinants of interest rate spread in Nepalese banking sectors, based on panel data for the 5 years period of 12 commercial banks, from 2012/13 to 2017/18. The data were collected from the respective banks' annual report, which has been published in the web page of the particular banks. To examine the determinants of interest rate spread, three different models like Pooled ordinary least square, Fixed Effects and Random Effects analysis methods have been employed. The Interest rate spread has been taken as the dependent variables and default risk, cash reserve ratio, return on assets, bank size, GDP growth rate, inflation and exchange rate as independent variables. The study found that there is positive and significant result between default risk, profitability and inflation rate with interest rate spread. The other remaining variables such as cash reserve ratio, size of the banks and GDP growth rate are positive, but insignificant result have been found except exchange rate negative and insignificant. Hence, the study concluded that the default risk, profitability and inflation rate were determinants of interest rate spread in Nepalese commercial banks perspectives.

KEYWORDS: Commercial Banks, Interest Rate Spread, Default Risk, Cash Reserve Ratio, Return on Assets, Bank Size, GDP Growth Rate, Inflation and Exchange Rate \&Nepal
\end{abstract}

Received: Apr 13 2020; Accepted: May 04, 2020; Published: Jun 03, 2020; Paper Id.: IJAFMRJUN20206

\section{INTRODUCTION}

In a country like Nepal, the net interest rate spread is the difference between the average yields that a financial institution receives from loans, along with other interest-accruing activities and the average rate it pays on deposits and borrowings. The net interest rate spread is a key determinant of a financial institution's profitability (or lack thereof). The net interest rate spread is instrumental to a bank's profitability. The spread rate (between loan and deposit) is to be reduced to $4.4 \%$ by all commercial banks by Ashad End 2077(Monetary Policy Highlights 2019/2020, p.7).

The spread between lending rate and deposit rate in Nepal has been widening over the years. It is noted that, this situation accounts for the slow growth rate of the economy, as private businesses are unable to borrow at the current interest rate, to expand their businesses so as to create employment to absorb the unemployed masses. There was a general perception that while lending rates were too high to induce any meaningful investment, and were at the core of low private sector investment in Nepal, however, borrowing rates were too low for savings mobilization (Bhattarai, 2017).

As cited by Njeri, Ombui and Kagiri (2015), IRS defined as, the difference between the interest rate 
charged on the borrowers and the rate paid to the depositors (Were \& Wambua, 2014).

Bank-specific factors have played major roles to determination of interest rate spread in banking industries (Atabaki, 2006).

This study has included the bank specific factors such as credit risk, cash reserve requirements, profitability and bank size; and macroeconomics factors of GDP growth rate, inflation and exchange rates have been employed. The five year panel data from 2012/13 to 2017/18 of twelve banks has been used. The major factors;default risk, profitability and inflation rate were determinants of interest rate spread in Nepalese commercial banks' perspectives.

The study has been further designed as follows: section two review of literature, research methodology in section third, section four results and discussion and summary and conclusion have been at the final section of the study.

\section{REVIEW OF LITERATURE}

The major review of literature related to this study is as follows. The literature has major role to conceptual framework development, hypothesis formulation and research design.

Khawaja and Din (2007) have asserted that interest rate spread in Pakistan bank by using panel data of 29 banks. The study found that interest-insensitive deposits in total bank deposits have played the main role to determination of interest rate spread.

Khan and Khan (2010) have analyzed the determinants of interest rate spreads of commercial banks in Pakistan of total sample 28 banks, and study period was 1997 to 2009. The findings of results show that interest rate spreads of commercial banks were determined by the banks' low cost of funding; operating expenses; and opportunities to earn income from non-core business activities. The macroeconomic variables, such as real GDP and interest rates also have positive influence on interest rate spread.

Were and Wambua (2014) have investigated the determinants of interest rate spread in banking sector of Kenya, based on panel data. The study has found that bank size, credit risk, return on average assets and operating costs were positively rated to interest rate spreads. Similarly, the bank liquidity ratio has a negative effect on the spreads. The macroeconomics variables monetary policy rate is positive significant.

Bhattarai (2017) has analyzed the determinants of interest rate spreads of commercial banks in Nepal. The study has employed the pooled OLS model, fixed effect model and random effect model to investigate the bank-specific variables affecting interest rate spread by using the panel data of 7 commercial banks, over the period of 6 years from 2010 to 2015. The estimated regression models reveal that default risk, profitability and bank size have significant and positive impact on interest rate spreads. Cash reserve requirement has negligible effect on interest rate spreads. The study concludes that the major determinants of commercial banks' interest rate spreads are default risk, profitability and bank size in Nepal.

Samoei and Toroitich (2019) have revealed the determinants of interest rate spread among commercial banks in Kenya, by using quarterly time series data for the period 2005 to 2014. The study has employed statutory reserve requirements, inflation rate, exchange rate volatility, Treasury Bill Rate, gross domestic product as independent variables to investigate interest rate spread. The study found that Treasury bill rate, reserves and gross domestic product, exchange rate volatility and inflation rate have statistically significant impact on the banking sector interest rate spreads, in Kenya. The study has recommended that there is need for policies to deal with reserve requirements, as well as putting in place 
measures, to stabilize the exchange rate volatility in Kenya.

\section{RESEARCH METHODOLOGY}

This study is based on the secondary panel data, which were gathered for the period 2012/13 to 2017/18 from twelve commercial banks in Nepal. The data were collected from the respective bank's annual report, which has been published in the web page of the particular banks. The data were collected for Interest rate spread, credit risk, cash reserve ratio, return on assets and bank size.

\subsection{The Model}

The data have been analyzed through the Gretl software 1.9.4 version. In the model, the dependent variable is Interest Rate Spread(IRS). Credit risk, cash reserve ratio, return on assets and bank size are independent variables. This study, based on three panel models such as pooled OLS model, fixed effect model and random effect model have been employed for data analysis. The model is presented asfollows:

$$
\begin{aligned}
& \mathrm{IRS}_{\mathrm{it}}=\beta \mathrm{O}+\beta 1 \mathrm{CR}_{\mathrm{it}}+\beta 2 \mathrm{CRR}_{\mathrm{it}}+\beta 3 \mathrm{ROA}_{\mathrm{it}}+\beta 4 \mathrm{SIZE}_{\mathrm{it}}+\mathrm{e}_{\mathrm{it}} \\
& \text { Where, } \\
& \beta_{0}=\text { Constant term } \\
& \beta 1 \text { to } \beta 4=\text { Coefficient of Variable } \\
& \text { IRS }_{\text {it }}=\text { Interest Rate Spread of } \mathrm{i}^{\text {th }} \text { bank in year } \mathrm{t} \\
& \mathrm{CR}_{\mathrm{it}}=\text { Credit Risk Ratio of } \mathrm{i}^{\mathrm{th}} \text { bank in year } \mathrm{t} \\
& \mathrm{CRR}_{\mathrm{it}}=\text { Cash Reserve Ratio of } \mathrm{i}^{\text {th }} \text { bank in year } \mathrm{t} \\
& \text { ROAit= Return on assets of } i^{\text {th }} \text { bank in year } t \\
& \text { SIZEit= Firm size of } \mathrm{i}^{\text {th }} \text { bank in year } \mathrm{t} \\
& \text { GDPGR }=\text { GDP Growth Rate in year } \mathrm{t} \\
& \mathrm{INF}=\text { Inflation Rate in year } \mathrm{t} \\
& \mathrm{ER}=\text { Exchange Rate with US } \$ \text { in year } \mathrm{t} \\
& \text { eit }=\text { Error term }
\end{aligned}
$$

\subsection{Variables Measurement and Expected Results}

The description of dependent and independent variables used in the study, and their measurement and expected sign are shown in table 2. 
Table 2: Variables Measurement and Expected Sign

\begin{tabular}{|c|c|c|c|c|}
\hline Variables & Measurement & Notation & $\begin{array}{l}\text { Expected } \\
\text { Sig }\end{array}$ & Source of Findings \\
\hline \multicolumn{5}{|c|}{ Dependent Variables } \\
\hline $\begin{array}{l}\text { Interest } \\
\text { Rate } \\
\text { Spread }\end{array}$ & $\begin{array}{l}\text { Different Interest } \\
\text { Rate between Loan } \\
\text { and Deposit }\end{array}$ & IRS & N/A & \\
\hline \multicolumn{5}{|c|}{ Bank Specific Variable } \\
\hline $\begin{array}{l}\text { Credit } \\
\text { Risk }\end{array}$ & $\begin{array}{l}\text { Non-performing } \\
\text { Loan to Total Loan }\end{array}$ & $\mathrm{CR}$ & + & $\begin{array}{l}\text { Chirwa and Mlachila (2004) and Sidiqqui (2012), Were } \\
\text { and Wambua (2014), Bhattarai (2017) }\end{array}$ \\
\hline $\begin{array}{l}\text { Cash } \\
\text { Reserve } \\
\text { Ratio } \\
\end{array}$ & NRB Rules & CRR & + & $\begin{array}{l}\text { Akinlo and Owoyemi (2012), Akinlo (2012), Bhattarai } \\
\text { (2017) }\end{array}$ \\
\hline $\begin{array}{l}\text { Return on } \\
\text { Total } \\
\text { Asset }\end{array}$ & $\begin{array}{l}\text { Net profit After } \\
\text { Tax to Total } \\
\text { Assets }\end{array}$ & ROA & + & $\begin{array}{l}\text { Afzal and Mirza (2010), Siddiqui (2012), Were and } \\
\text { Wambua (2013), Bhattarai (2017) }\end{array}$ \\
\hline Bank Size & $\begin{array}{l}\text { Natural Logarithm } \\
\text { of Total Asset }\end{array}$ & LnTA & + & $\begin{array}{l}\text { Maudos and Solis (2009), Afzal and Mirza (2010) Were } \\
\text { and Wambua(2014), Bhattarai (2017) }\end{array}$ \\
\hline \multicolumn{5}{|c|}{ Macroeconomic Variables } \\
\hline $\begin{array}{l}\text { GDP } \\
\text { Growth } \\
\text { Rate }\end{array}$ & GDP Growth Rate & GDPGR & + & $\begin{array}{l}\text { Were and Wambua (2013), Rebei (2014), Churchill et al } \\
\text { (2014), Neli (2015), Kiptui (2014), Folawewo and } \\
\text { Tennant(2008), Niyimbanira et al (2015), Akinlo and } \\
\text { Owoyemi (2012), Grenade (2007), Crowley (2007), } \\
\text { Afanasieff et al(2002) }\end{array}$ \\
\hline Inflation & Inflation Rate & INF & + & $\begin{array}{l}\text { Atabaki, M (2006), Nazarian and Hasheminejad, Were } \\
\text { and Wambua (2013), Rebei (2014), Sheriff and Amaoko } \\
\text { (2014), Churchill et al (2014), Ghasemi and Rostami } \\
\text { (2016), Neli (2015), Folawewo and Tennant (2008), } \\
\text { Niyimbanira et al (2015), Akinlo and Owoyemi (2012), } \\
\text { Crowley (2007), Afanasieff et al (2002), Tarus et al } \\
\text { (2012) }\end{array}$ \\
\hline $\begin{array}{l}\text { Exchange } \\
\text { Rate }\end{array}$ & $\begin{array}{l}\text { NRS and US\$ } \\
\text { Exchange Rate }\end{array}$ & ER & + & Nazarian and Hasheminejad (2009) \\
\hline
\end{tabular}

\section{RESULTS AND DISCUSSIONS}

\subsection{Descriptive Statistics}

Table 3 shows that the average interest spread rate is 4.28 percent, whereas minimum and maximum rates are 2.49 percent and 7.15 percent, respectively. The standard deviation is less than one percent. It revealed that there is low deviation in term of interest spread rate. The sample commercial banks in Nepal have near close in the interest spread rates. The non-performing loan ratio i.e. called default risk ratio is, minimum 0.18 percent to maximum 24.7 percent. It shows that there is vast differentiate between the range. 
Table 3: Descriptive Statistics

\begin{tabular}{|l|c|c|c|c|c|}
\hline \multicolumn{1}{|c|}{ Variable } & Scale & Mean & S.D. & Min & Max \\
\hline ISR & $\%$ & 4.28 & 0.996 & 2.49 & 7.15 \\
\hline DR & $\%$ & 2.51 & 3.65 & 0.180 & 24.7 \\
\hline CRR & $\%$ & 20.9 & 21.5 & 5.49 & 92.8 \\
\hline ROA & $\%$ & 1.71 & 0.920 & -3.43 & 3.12 \\
\hline LnTA & Ln & 25.0 & 0.596 & 23.8 & 27.5 \\
\hline GDPGR & $\%$ & 4.60 & 2.50 & 0.400 & 7.40 \\
\hline INF & $\%$ & 7.32 & 1.98 & 4.48 & 9.90 \\
\hline ER & NRS & 103. & 3.44 & 98.3 & 106. \\
\hline $\begin{array}{l}\text { Source: Annual Report of Sample commercial banks and Results are } \\
\text { Drawn from Gretl Software 1.9.4 Version }\end{array}$
\end{tabular}

The average profitability ratio called ROA is 1.71 percent. Which rage are negative 3.43 percent to 3.12 percent respectively. The GDP growth rate is minimum 0.40 percent 7.40 percent. It is very low due to the earthquake $2015 / 16$ in Nepal than after it is in the trend of increasing. The average inflation rate is 7.32 which is higher than these days. It has been increasing trend in the coming year (other than effect of COVID-19 -2020).

\subsection{Correlation Analysis}

The table 4 reveals the Pearson correlation coefficient matrix of study variables. The relation between default risk ratio, cash reserve ratio, return on assets, size of the banks, GDP growth rate, inflation and exchange rate with US dollars and interest spread rate are found. There is positive relationship between default risk ratios, cash reserve ratio, return on assets, size of the banks and inflation and interest spread rate. It shows that, these variables are moving in the same direction with the interest rate spread. Whereas, the relation between GDP growth rate and US dollar exchange rate have negativity with interest rate spread.

Table 4: Correlation Matrix of Study Variables

\begin{tabular}{|c|c|c|c|c|c|c|c|l|}
\hline ISR & DR & CRR & ROA & LnTA & GDPGR & INF & ER & Variables \\
\hline 1.0000 & 0.2185 & 0.1305 & 0.2136 & 0.2602 & -0.0379 & 0.1727 & -0.1429 & ISR \\
\hline & 1.0000 & 0.0251 & -0.6311 & -0.1640 & -0.0220 & 0.0583 & -0.2049 & DR \\
\hline & & 1.0000 & 0.0831 & -0.1094 & 0.0190 & 0.0088 & -0.0717 & CRR \\
\hline & & & 1.0000 & 0.5419 & -0.0095 & -0.1089 & 0.2661 & ROA \\
\hline & & & & 1.0000 & 0.1406 & -0.2604 & 0.3189 & LnTA \\
\hline & & & & & 1.0000 & -0.7379 & -0.1307 & GDPGR \\
\hline & & & & & & 1.0000 & -0.2879 & INF \\
\hline & & & & & & & 1.0000 & ER \\
\hline
\end{tabular}

The result of negative relationship shows that, if interest rate spread increases, the GDP growth rate and US dollars exchange rate decrease and vice-versa. The correlation coefficient is less than 0.80 ; it is represented that there is absence of multi collinearity among predictors.

\subsection{Regression Analysis}

Table 5 represents the regression results of determinants of interest rate spread, by three different methods like Pooled ordinary least square, Fixed Effects and Random Effects analysis methods. 
Table 5: Regression Results of Determinants of Interest Rate Spread of Sample Commercial Banks in Nepal

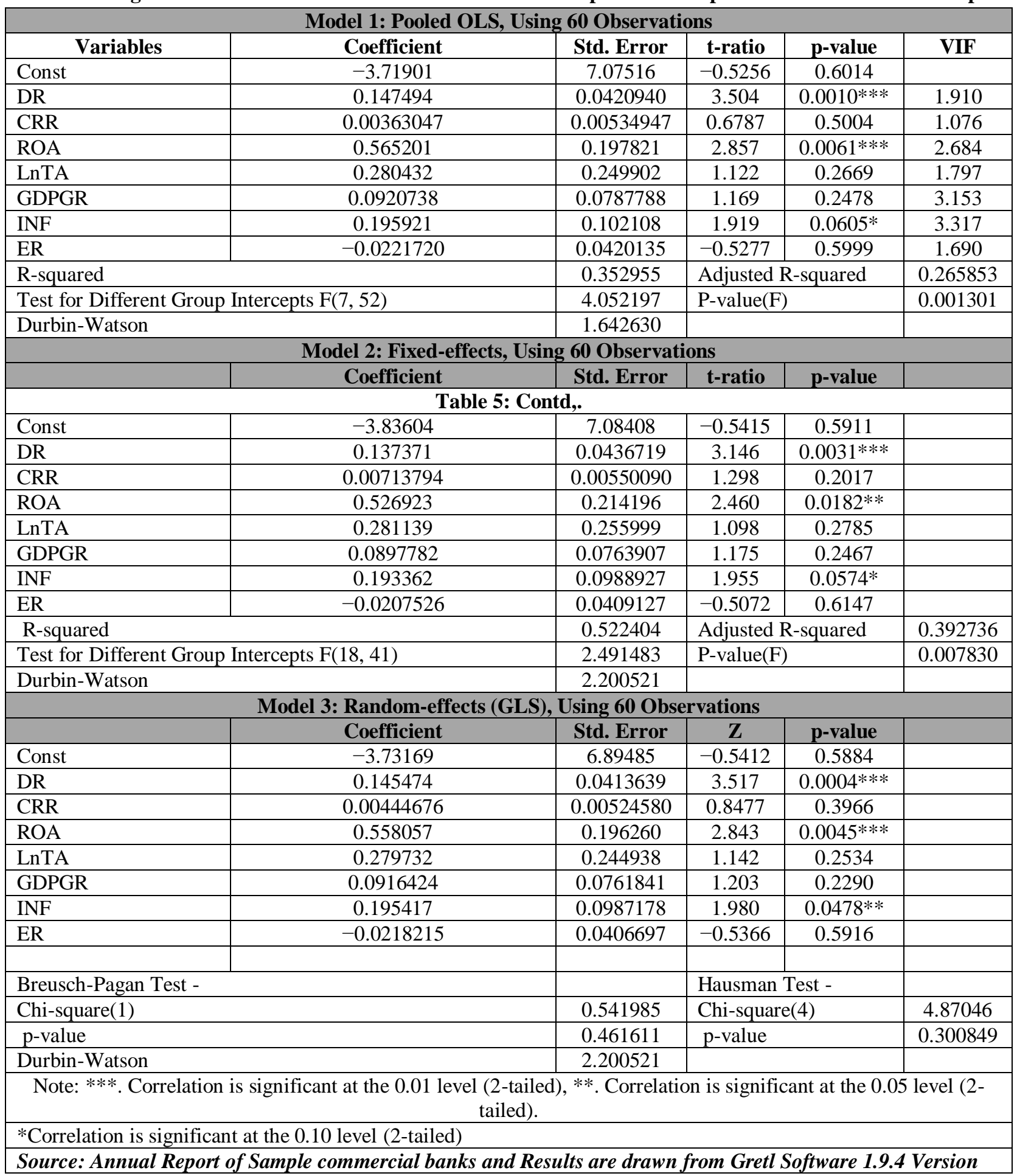

The value of R-square is relatively high in the Fixed Effects Model i.e. 39.23\%. The explanatory power of model is very low, because there is $60.77 \%$ variation explanation by other variables. There is significant and positive results found between interest rate spread and default risk ratio in all models. It shows that when default risk increases, the interest also increases in Nepalese sample commercial banks. The result is consistent with findings of Chirwa and Mlachila (2004) and Sidiqqui (2012), Were and Wambua (2013) and Bhattarai (2017). Similarly, the profitability is found positive and significant with interest rate spread. The results show that higher profitable Nepalese commercial banks always have higher 
interest spread rate. The result is found, as per priori hypothesis. The result of the study is similar with the inference in previous studies of experts like Afzal and Mirza (2010), Siddiqui (2012), Were and Wambua (2013), and Bhattarai (2017). Furthermore, the inflation rate is positive and significant at 10 percent level. The result is consistent with the findings of Afanasieff et al (2002), Atabaki, M (2006), Crowley (2007), Folawewo and Tennant (2008), Akinlo and Owoyemi (2012), Tarus et al (2012), Were and Wambua (2013), Rebei (2014), Sheriff and Amaoko (2014), Churchill et al (2014), Neli (2015), Niyimbanira et al (2015), and Ghasemi and Rostami (2016). It shows that higher the inflation rate demand, higher isthe interest rate spread in the countries like Nepal. This is also, as per priori expectation.

The other remaining variables such as cash reserve ratio, size of the banks and GDP growth rate are positive, but insignificant results have been found except exchange rate negative and insignificant. The results of findings point out that, these variables have positive role for interest rate spread, but could not effects significantly in Nepalese sample commercial banks. The result has been similarly found in the three different models.

\section{SUMMARY AND CONCLUSIONS}

The study has investigated on the determinants of interest rate spread in Nepalese banking sectors, based on panel data analysis. The panel data were gathered for the 5 year period, from 2012/13 to 2017/18 twelve commercial banks in Nepal. The data were collected from the respective bank's annual report, which has been published in the web page of the particular banks. To examine the determinants of interest rate spread, three different methods like Pooled ordinary least square, Fixed Effects and Random Effects analysis methods have been employed. The Interest rate spread has been taken as dependent variables, and default risk, cash reserve ratio, return on assets, bank size, GDP growth rate, inflation and exchange rate as independent variables. The study found that, there is positive and significant result between default risk, profitability and inflation rate with interest rate spread. The other remaining variables such as cash reserve ratio, size of the banks and GDP growth rate are positive, but insignificant results have been found, except exchange rate negative and insignificant. Hence, the study concluded that the default risk, profitability and inflation rate were determinants of interest rate spread, in the Nepalese commercial banks' perspectives.

\section{REFERENCES}

1. Ahmad, N., Ahmad, Z., \& Usman, A. (2011). Determinants of performance:A case of life insurance sector of Pakistan. International Research Journal of Finance and Economics 6(1), 123-128.

2. Akotey, J. O., Sackey, F. G., Amoah, L., \& Manso, R. F. (2013). The financial performance of life insurance companies in Ghana. The Journal of Risk Finance, 14(3), 286-302.

3. Allen, L.O., (1988). The determinants of bank interest margins: a note. J. Financ. Quant. Anal. 23 (2), 231-235.

4. Atabaki, M. (2006). Factors affecting the interest rates received and paid between banks in Iran using a master data. MSc Dissertation, Shahid Beheshti University.

5. Bhattarai, Y.R.(2017) Determinants of interest rate spreads of commercial banks in Nepal. International Journal of Management and Economics Invention, 3(6), 1258-1270.

6. Ghasemi, A. \& Rostami, M. (2015). Determinants of interest rate spread in banking industry. International Journal of Applied Research 2015, 1(9), 338-346.

7. Ghasemi, A. \& Rostami, M. (2016). Determinants of interest rate spread in banking industry. ECOFORUM, 5, 1 (8), 320-331 
8. Rani, Poonam, and Veerpaul Kaurmann. "Contagion Effect of Macro Economic Variables on Ipo Listing Activity: A Time Series Analysis in Indian Context."International Journal of Business Management \& Research (IJBMR) 7. 4, Aug 2017, 47-52

9. Ho, T., Saunders, A., 1981. The determinants of bank interest margins: theory and empirical evidence. J. Financ. Quant. Anal. 16 (4), 581-600.

10. Hsiao, C., 2007. Analysis of Panel Data. Cambridge University Press, New York.

11. Khan, M.H \& Khan, B. (2010). What drives interest rate spreads of commercial banks in Pakistan? Empirical Evidence based on Panel Data. SBP Research Bulletin, 6(2), 15-36.

12. Khawaja, M. and Din, M. (2007). Determinants of interest spread in Pakistan. The Pakistan Development Review 46: 2 (Summer 2007), pp. 129-143

13. Mohideen, OM Haja, and M. Parveen. "A Study on Predicting Financial Performance Using Duo Pont Analysis in Cipla Pharmaceutical Company." International Journal of Accounting and Financial Management Research (IJAFMR), ISSN (P) (2014): 2249-6882.

14. Mannasoo, K., 2012. Determinants of Bank Interest Spread in Estonia, EESTI-PANK Working Paper No. 1/2012.

15. Njeri1, B.K., Ombui, K., \& Kagiri, A.W. (2015). Determinants of interest rate spread of commercial banks in Kenya. International Journal of Science and Research (IJSR), 4(11), 617-620.

16. Onodugo, Vincent, et al. "Non-oil export and economic growth in Nigeria: A time series econometric model." International Journal of Business Management \& Research (IJBMR) 3.2 (2013).

17. Samoei,S.K. \& Toroitich, E.K. (2019). Determinants of Interest Rate Spread among Commercial Banks in Kenya. International Journal of Research and Innovation in Social Science (IJRISS), III (VI), 147-152.

18. Al-Ethary, Adnan Dawood M., Myieh Shbeeb AL-Shamri, and Sadek Ali Taan Al-Jobory."The Impact of economic openness degree on GDP growth in Malaysia and some neighboring countries for the period 1990-2010."

19. Were, M., \& Wambua, J. (2014). What factors drive interest rate spread of commercial banks? Empirical evidence from Kenya. Review of Development Finance, 4 (2014) 73-82 